Grahame, E. R. M., K. D. Martin, E. A. Gow, and D. R. Norris. 2021. Diurnal and nocturnal habitat preference of Eastern Whip-poor-wills (Antrostomus vociferus) in the northern portion of their breeding range. Avian Conservation and Ecology 16(2):14. https://doi.org/10.5751/ ACE-01929-160214

Copyright (C) 2021 by the author(s). Published here under license by the Resilience Alliance.

Research Paper

\title{
Diurnal and nocturnal habitat preference of Eastern Whip-poor-wills (Antrostomus vociferus) in the northern portion of their breeding range
}

Elora R. M. Grahame ${ }^{1}$, Kayla D. Martin ${ }^{1}$, Elizabeth A. Gow ${ }^{1,2}$ (D) and D. Ryan Norris ${ }^{1}$ (is

${ }^{1}$ Department of Integrative Biology, University of Guelph, Guelph Ontario, Canada, ${ }^{2}$ Birds Canada, Port Rowan, Ontario, Canada

\begin{abstract}
How animals choose habitats during periods of inactivity, such as roosting or resting, is an often overlooked aspect of habitat preference that can differ significantly from how habitats are selected during active periods. Eastern Whip-poor-wills (Antrostomus vociferus) are migratory nocturnal aerial insectivores that breed throughout eastern North America. In Canada, Whip-poor-will populations have declined by over $30 \%$ in the past 20 years, and a comprehensive understanding of their diurnal and nocturnal habitat selection is required for developing effective conservation management strategies. From 447 radio-telemetry locations of 12 female and 32 male adult Whip-poor-wills radio-tracked over three breeding seasons (2018-2020), we used resource selection functions to assess habitat preference of Whip-poor-wills in the northern portion of their breeding range within Torrance Barrens Dark-Sky Preserve, central Ontario. Locations were taken both at night when individuals were primarily active and during the day when they were roosting. During both day and night, Whip-poor-wills used deciduous forest and shrubland more often than expected based on availability, while they avoided open water and wetlands. At night, Whip-poor-wills preferred to use mixed forest and rock barrens, while there was no difference between use and availability of these land cover types during the day. Our results suggest that shrubland and deciduous forest are important as both foraging and roosting habitat for Whip-poor-wills in this population, while rock barrens and mixed forest are important for foraging. While landscapes dominated by rock barrens interspersed with patches of shrubland and deciduous and mixed forests are uncommon, they could play an important role in the persistence of declining Whip-poor-will populations, particularly in the northern part of their breeding range. Conservation efforts for northern breeding Whip-poor-wills should focus on surveying and protecting similar rock barrens landscapes and those with a comparable patchwork of land cover features.
\end{abstract}

\section{Les préférences d'habitats diurnes et nocturnes de l'engoulevent bois-pourri (Antrostomus vociferus) dans la partie nord de leur zone de nidification}

RÉSUMÉ. La manière dont les animaux choisissent leurs habitats pendant les périodes d'inactivité, par exemple pour la nidification ou le repos, est un aspect souvent négligé de la préférence d'habitat qui peut varier considérablement selon la manière dont les habitats sont choisis pendant les périodes actives. L'engoulevent bois-pourri (Antrostomus vociferus) est un insectivore aérien nocturne migrateur qui se reproduit dans tout l'est de l'Amérique du Nord. Au Canada, les populations d'engoulevents bois-pourri ont décliné de plus de $30 \%$ au cours des 20 dernières années et une compréhension complète de la sélection de leur habitat diurne et nocturne est nécessaire pour développer des stratégies efficaces de gestion de la conservation. À partir de 447 localisations par radio-télémétrie de 12 engoulevents bois-pourri femelles et 32 mâles adultes pendant trois saisons de reproduction (2018-2020), nous avons utilisé des fonctions de sélection des ressources pour évaluer la préférence des engoulevents en termes d'habitat dans la partie nord de leur zone de reproduction au sein de la réserve naturelle de Torrance Barrens Dark-Sky, au centre de l'Ontario. Les localisations ont été mesurées à la fois de nuit, lorsque les individus sont plutôt actifs, et pendant la journée, lorsqu'ils étaient dans leur nid. De jour comme de nuit, les engoulevents fréquentaient des forêts d'arbres à feuillage caduc et des broussailles plus fréquemment que prévu en fonction de leur disponibilité, alors qu'ils évitaient les plans d'eau et les marécages. De nuit, les engoulevents privilégiaient la forêt mixte et les landes rocheuses, alors qu'il n'existait pas de différence entre l'utilisation et la disponibilité de ces types d'abris terrestres pendant la journée. Nos résultats suggèrent que les broussailles et les forêts de feuillus sont importants en tant qu'habitats de nourriture et de nidification pour les engoulevents de cette population, alors que les landes rocheuses et les forêts mixtes sont des sites de nourriture majeurs. Même si les paysages dominés par des landes rocheuses entrecoupées de broussailles et de forêts de feuillus et mixtes sont peu fréquents, ils pourraient jouer un rôle important dans la persistance des populations déclinantes d'engoulevents, en particulier dans la partie nord de leur zone de reproduction. Les efforts de conservation des engoulevents reproducteurs dans le nord devraient se concentrer sur l'observation et la protection de paysages similaires de landes rocheuses et de ceux qui présentent des caractéristiques végétales comparables.

Key Words: Aerial insectivore; foraging; habitat; nightjar; nocturnal; roosting; activity

Erratum: Corrections to this paper were made on 17 January 2021.

1) The specific name Antrostomus vociferous was corrected to Antrostomus vociferus throughout the paper.

2) Reference to the Anishinaabemowin common name "Waakowazh" has been removed because whip-poor-wills are recognized by multiple names in Anishinaabek culture.

3) The Acknowledgments were changed to thank Sherrill Judge of Shawanaga First Nation and Brian McInnes from Wasauksing First Nation. 


\section{INTRODUCTION}

Understanding the types of habitats an animal prefers versus those they disfavor provides insight into how an individual uses resources (Manly 1993, Boyce et al. 2002, Beyer et al. 2010), which can be important for predicting population growth, individual survival, and reproduction (Fretwell and Lucas 1969, Franklin et al. 2000). Inferences drawn from habitat preference (i.e., habitats used more than their availability) are also widely used for developing conservation and management strategies (e.g. Boyce and Waller 2003, Baldwin et al. 2006). Habitat requirements of a species can vary geographically (Osborne and Seddon 2012) depending either on the relative availability of habitats between landscapes (Wiens and Cody 1985, Vallecillo et al. 2010) or differences in individual preferences between populations (Murphy and Lovett-Doust 2007). This emphasizes the importance of understanding patterns of habitat preference across a species ' range, particularly for declining or at-risk species.

An often overlooked aspect of habitat preference is how animals choose habitats for periods of inactivity such as resting or roosting (Lima et al. 2005, Moe et al. 2007). However, habitats preferred for roosting can be quite different from those favored during active periods. For example, in breeding California Spotted Owls (Strix occidentalis occidentalis), use of burned stands varied with the severity of the burn, and the owls' selection of low-severity burned sites for roosting contrasted with their use of high-severity burned sites for foraging (Bond et al. 2009). American Woodcocks (Scolopax minor) foraged in moist coniferous and mixed wood forests during the day, but some individuals commuted to forest openings such as fields for nighttime roosts, possibly to avoid predators (Masse et al. 2013). In wintering Northern Pintails (Anas acuta), the selection of flooded rice paddies for nighttime foraging contrasted with the nearby reservoir used for roosting during the day (Parejo et al. 2019). Failure to account for key behavioral states or time periods could lead to a misrepresentation of a species' habitat requirements (Gillings et al. 2005, Framis et al. 2011, McGarigal et al. 2016). Understanding such needs may be particularly important for species with diurnal roosting that rely on camouflage from daytime predators (Körtner and Geiser 1999).

One species lacking specific information on habitat preference while roosting is the Eastern Whip-poor-will (Antrostomus vociferus; hereafter "Whip-poor-will"). The Whip-poor-will, a member of the nightjar family (Caprimulgidae), is a migratory nocturnal aerial insectivore that breeds in eastern North America and overwinters from the Gulf Coast of Mexico to Honduras (English et al. 2017a, Tonra et al. 2019, Cink et al. 2020). Whippoor-wills forage at dusk and into the night, using their low-light vision to detect their primary prey, moths and beetles (Mills 1986, Cink et al. 2020). They forage by sallying, making short flights from a rock or branch to capture prey mid-air before returning to their perch (Cink et al. 2020). Whip-poor-wills exhibit cryptic plumage, patterned with brown, buff, and grey tones, providing camouflage from predators (Cleere 1998, Cink et al. 2020), which is particularly important as they nest on the ground and roost during the day. Boreal roost sites for another ground-nesting North American nightjar species, the Common Nighthawk (Chordeiles minor), include trees and logs but not bare ground and the preference of these arboreal roosts may be due to factors including visibility of the surrounding area and predator avoidance (Fisher et al. 2004, Foley 2018). Recent evidence from three African nightjar species (Caprimulgus spp.) demonstrated that nightjars maximize camouflage and increase nest success by actively choosing backgrounds that best match the pattern, luminance, and color of their plumage as seen by potential predators (Troscioto et al. 2016, Stevens et al. 2017). While predators for adult Whip-poor-wills are not well documented, one adult male tracked as part of our ongoing study was eaten by an aerial predator, possibly a Barred Owl (Strix varia; unpublished data).

Whip-poor-wills are widely known across their range for their repetitive, onomatopoetic "whip-poor-will" call and secretive behavior, with references to their mysterious nocturnal song found throughout music and folklore. Unfortunately, however, Whip-poor-wills are becoming less common due to population declines. In Canada, Whip-poor-will numbers have declined by 2.3\% per year from 1970-2017 (Smith et al. 2017), with a total population decline of over 30\% since 1999 (COSEWIC 2009). These steep declines resulted in the 2011 designation of the species as threatened under Canada's Species at Risk Act (COSEWIC 2009), and in 2018, Whip-poor-wills were up-listed from least concern to near threatened by the International Union for the Conservation of Nature (IUCN; BirdLife International 2018). Because habitat loss and degradation (such as succession of open habitat to shrubs and trees) are listed as threats to the species (COSEWIC 2009), information on specific habitat requirements can help direct management strategies and define critical habitat.

Several studies have examined habitat use or occupancy of Whippoor wills. In the southern part of their breeding range, Whippoor-wills in North Carolina used the edges of previously thinned or harvested loblolly pine (Pinus taeda) plantations (Wilson and Watts 2008). Farther north, in Massachusetts, high numbers of Whip-poor-wills were found in pine-oak barrens, as well as in thinned open-canopy stands of pitch pine (Pinus rigida; Garlapow 2007). In the northernmost part of their range in central Ontario, Whip-poor-wills showed a preference for stands of red pine (Pinus resinosa) interspersed with clear-cut blocks (Tozer et al. 2014). Recent studies in eastern Ontario showed that Whip-poor-wills frequented alvars, rock barrens, and old fields along forest edges (English et al. 2017b), and were more likely to occupy areas with wetlands and large patchy forests (Vala et al. 2020). In northwestern Ontario, Whip-poor-wills were found in open areas such as clearcuts, burns, and wetlands (Rand 2014, Farrell et al. 2017). However, while most studies analyzed locations collected when Whip-poor-wills were most active from dusk to dawn, only two studies recorded daytime roost locations. Whip-poor-wills in northern New York State selected closedcanopy forests for daytime roosts (Spiller 2019), while those in Massachusetts selected scrub-oak and pitch pine (Akresh and King 2016). When compared to foraging sites at locations within the same study area, roost locations had a higher maximum height of understory vegetation and nearly double the tree density (Spiller 2019), suggesting that Whip-poor-wills may select roosting sites that maximize concealment from potential diurnal predators such as red fox (Vulpes vulpes), members of the weasel family (Mustelidae), raccoons (Procyon lotor), and eastern chipmunk (Tamias striatus; English et al. 2017b, ERMG personal observation). 
Here, we examined third-order habitat selection (i.e., preference of habitats within a home range; Johnson 1980) of radio-tracked Whip-poor-wills in Torrance Barrens Dark-Sky Preserve, central Ontario, during the daytime and nighttime. We assessed habitat preference using resource selection functions (RSFs) by pairing Whip-poor-will locations with randomly generated locations within the study area (Table 1). We examined two separate hypotheses to explain daytime and nighttime Whip-poor-will habitat preference. The optimal foraging hypothesis proposes that animals maximize energy gained from food while minimizing energy expenditure to obtain food and possibly thermoregulate (Krebs et al. 1977, Krebs 1978). Open areas are thought to provide optimal conditions for foraging Whip-poor-wills because they maximize available moonlight, providing clear sight lines for hunting prey (Mills 1986, Cink et al. 2020). In Torrance Barrens, rock barrens provide these conditions and they are also typically bordered by small patches of forest, where moths, a primary food source (Cink et al. 2020), are likely most abundant (Sharov et al. 1997, Burford et al. 1999, Summerville and Crist 2003). Therefore, we predicted that at night, Whip-poor-wills would be located in rock barrens more often than randomly generated locations. During inactive periods, animals typically rest in places where they can avoid predators (Lima et al. 2005). Following this, we hypothesized that during the day, Whip-poor-wills would select their roosting sites in mixed and deciduous forest to avoid predators by blending in with patterns of branches, logs, and leaf litter.

Table 1. Percent composition of land cover types within a sample of used ( $\mathrm{n}=89$ daytime, 358 nighttime) and available (random; $\mathrm{n}=890$ daytime, 3,580 nighttime) locations with $15 \mathrm{~m}$ buffers. All locations were recorded for tagged Whip-poor-wills at Torrance Barrens, Ontario during the breeding season from 2018-2020. Available locations approximate the habitat composition of the study site, while used locations represent land cover selected by Whip-poor-wills.

\begin{tabular}{lccccc}
\hline \hline $\begin{array}{l}\text { Land Cover Type } \\
(\%)\end{array}$ & \multicolumn{2}{c}{ Used Locations } & & \multicolumn{2}{c}{ Available Locations } \\
\cline { 2 - 3 } \cline { 5 - 6 } & Day & Night & & Day & Night \\
\hline Deciduous Forest & 21.9 & 9.0 & & 7.1 & 6.5 \\
Mixed Forest & 8.9 & 16.4 & & 11.5 & 11.1 \\
Road & 0.5 & 2.4 & & 2.7 & 2.6 \\
Rock Barrens & 16.0 & 21.2 & & 17.3 & 17.1 \\
Shrubland & 44.6 & 40.8 & & 34.7 & 33.2 \\
Water & 0.2 & 0.3 & & 6.1 & 6.4 \\
Wetland & 7.9 & 9.9 & & 20.6 & 23.1 \\
TOTAL & 100 & 100 & & 100 & 100 \\
\hline
\end{tabular}

\section{METHODS}

\section{Study site}

In 2018-2020, from May - September, we studied Whip-poor-wills in Torrance Barrens Dark-Sky Preserve (hereafter "Torrance Barrens"), District of Muskoka, in south-central Ontario,

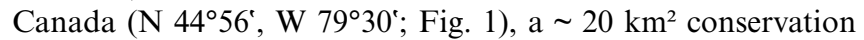
reserve surrounded by crownland that is relatively unprotected in terms of use and development as compared to the land within the boundary of the conservation area. The study site lies on the traditional lands of the Anishinaabe and Huron-Wendat. The landscape is characterized by a mosaic of land cover types, including upland areas dominated by eastern white pine (Pinus strobus), northern red oak (Quercus rubra), and white oak (Quercus alba). Ridges within these areas consist of exposed Precambrian bedrock ("rock barrens") dominated by mosses, lichens, and low plants such as common juniper (Juniperus communis). Ridges are separated by lower elevation thicket swamps, fens, sphagnum bogs, and lakes or ponds. Vegetation surrounding low areas includes shrubland and forests dominated by birch (genus Betula), aspen (genus Populus), and alder (genus Alnus). Torrance Barrens is used by the public for recreational activities such as hiking, camping, and stargazing. Although there are maintained hiking trails, people often walk off-trail to explore the open bedrock areas. One road and one snowmobile trail also run through the study site. The site features high Whip-poor-will abundance relative to the broader region of south-central Ontario (Mills 2007).

\section{Radio telemetry}

We captured Whip-poor-wills by attracting them to mist nets using audio playback lures ("whip-poor-will" call) and decoys made of cut and painted corrugated plastic. We checked mist nets at least every 10- to 20-min. On occasion, we captured Whip-poorwills sitting on the ground at night by slowly approaching with a headlamp and gently placing a dip net over the bird. Upon capture, Whip-poor-wills were banded, measured, and tagged with digitally-encoded nano-tags (models: NTQB2-4-2S and NTQB2-6-1, Lotek Wireless Inc., Newmarket, Ontario) using the backpack-style harness described by $\mathrm{Ng}$ et al. (2018). Including harness materials (elastic beading cord and small beading crimps), the transmitters weighed approximately $1.4 \mathrm{~g}$ and $1.9 \mathrm{~g}$, respectively, amounting to less than $5 \%$ of the individual bird's body mass. We released all birds at their site of capture and used red filters on headlamps while observing them fly away so as to minimize obstructing their vision. We recorded tracking locations for 44 adult Whip-poor-wills, of which twelve individuals were female and 32 were male. Eight males and two females were recaptured in subsequent years and tracked during two separate breeding seasons. We monitored seven individuals during 2018 , 23 in 2019, and 24 in 2020.

At least 24-hrs after tag deployment, we tracked Whip-poor-wills using an SRX600 or SRX800 telemetry receiver and a threeelement Yagi antenna (Lotek Wireless Inc., Newmarket, Ontario) or $\mathrm{VHF}$ receiving $\mathrm{H}$ antenna (Telonics, Inc., Mesa, Arizona) primarily between $1.5 \mathrm{hrs}$ before sunset to $4 \mathrm{hrs}$ after sunset. When fieldwork logistics allowed us to do so, birds were tracked later into the evening until right before sunrise. Male Whip-poor-wills were sometimes found incubating eggs or nestlings late in the evening (typically after midnight), but all nest points were omitted from the database for this habitat analysis. Daytime locations were those recorded before the official sunset time, and nighttime locations were recorded after sunset. Whip-poor-wills primarily roosted in the daytime and then began foraging at dusk. We tracked Whip-poor-wills until they could be detected by sight or sound, then paused and waited at a distance (typically 10-20 m) to record behavioral observations, such as singing, foraging, or roosting. As we watched and waited, our headlamps were switched to red light to minimize the influence of our presence 
Fig. 1. The process used for estimating habitat preference or avoidance by Whip-poor-wills. (1) Used daytime and nighttime Whip-poor-will locations were plotted on a land cover map of the study site. (2) Available daytime and nighttime locations were randomly placed within the study site at a ratio of 10 available locations: 1 used location. (3) The area of each land cover type was measured within each location buffer and converted to a percentage. Inset map shows the location of Torrance Barrens (bird icon) in central Ontario, Canada.

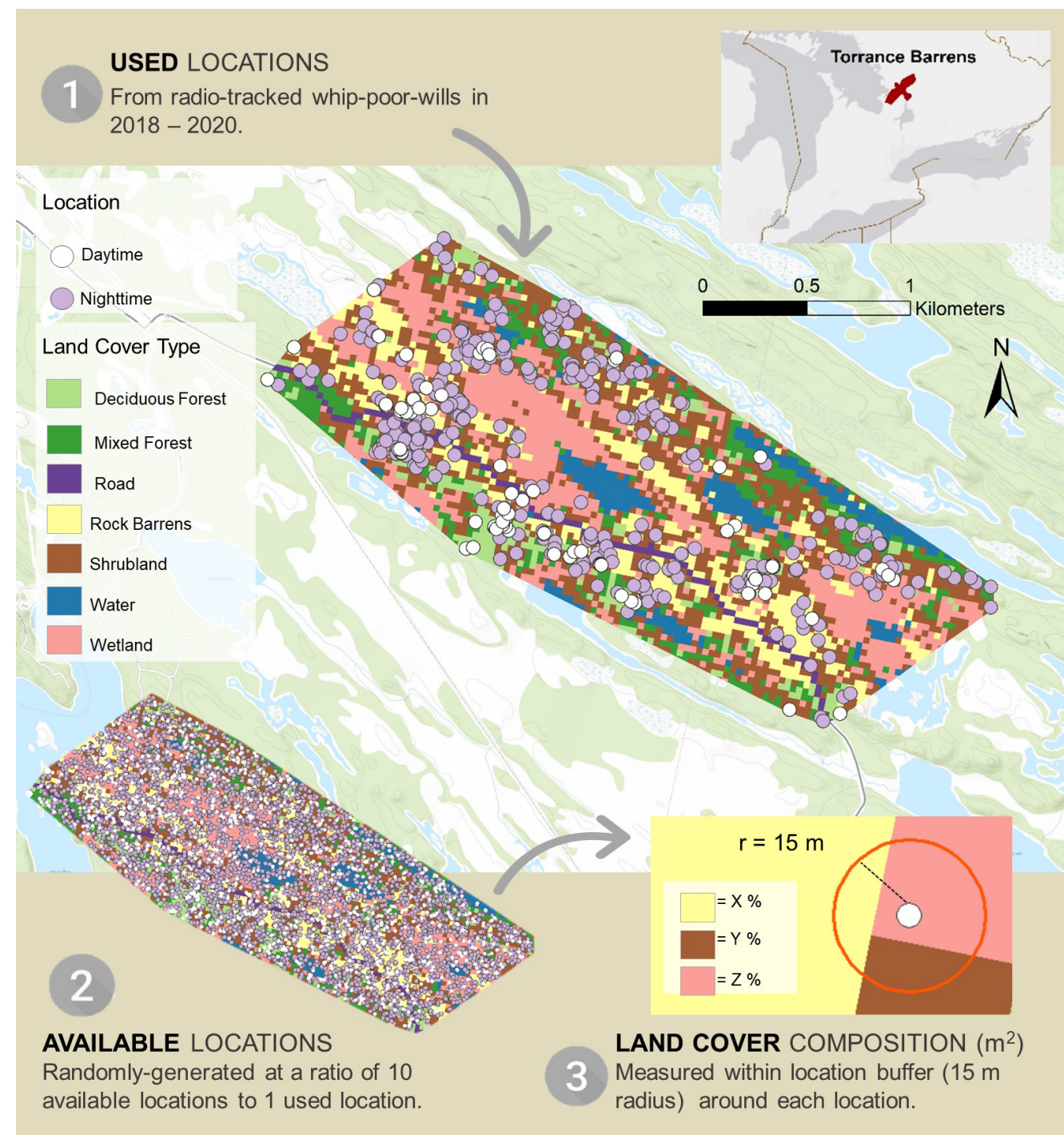

on the bird's vision. Once a bird left the location, we moved to the now-vacant location and took Universal Transverse Mercator (UTM) coordinates using a GPS (Garmin Ltd., Olathe, Kansas). For birds observed in trees, we took UTM coordinates directly under the bird. When Whip-poor-wills were roosting low to the ground, we approached only after waiting to be sure the bird was truly roosting and not just pausing for a moment before taking flight to forage. Birds roosting at night were alert and possibly opportunistically foraging or thermoregulating as compared to daytime roosts when their eyes were closed for rest. Once approached, roosting Whip-poor-wills tended to flush at distances $<5 \mathrm{~m}$ away.
Before analysis, we reviewed tracking data to exclude location points unsuitable for analysis. Because the focus of this study was foraging and roosting habitat preference, we excluded nest locations from tracked individuals found incubating eggs or brooding chicks. To maintain independence, we also excluded points taken less than $30 \mathrm{~min}$ apart for any individual. Sharps et al. (2015) tracked European Nightjars (Caprimulgus europaeus) using a minimum interval of 10 min for active birds and $30 \mathrm{~min}$ for inactive birds, so we chose to use a conservative 30 min interval for both daytime and nighttime locations. After removing unsuitable locations, there was a total of 447 locations used for the analyses (range: 1 - 37 per individual). 


\section{Land cover and study area boundary}

We used the Geographic Information System (GIS) program ArcMap (v. 10.7.1, Environmental Systems Research Institute, Redlands, CA) to delineate and analyze seven land cover types within the study area (Table 2). Land cover data were obtained from the 2019 Annual Crop Inventory, which broadly covers regions of Canadian provinces where agricultural crops are grown. The GIS layer is based on satellite and radar imagery with a spatial resolution of $30 \mathrm{~m}$ and an accuracy of at least $85 \%$ (Agriculture and Agri-Food Canada 2019). Due to the negligible amount of grassland and coniferous forest in the study area $(0.29 \%$ and $0.22 \%$ of total land cover within the study area, respectively), we combined grassland and rock barrens into one layer and similarly combined the mixed forest and coniferous layers.

Table 2. Summary of variables used in the resource selection function models. Variables were used to estimate the probability of a Whip- poor-will using a habitat with those characteristics. Descriptions based on Agriculture and Agri-Food Canada's Annual Space-Based Crop Inventory for Canada, 2019.

\begin{tabular}{|c|c|}
\hline Variable & Description \\
\hline $\begin{array}{l}\text { Deciduous } \\
\text { Forest }\end{array}$ & Predominantly deciduous forests or treed areas. \\
\hline Mixed Forest & $\begin{array}{l}\text { Forest that is a combination of both the coniferous and } \\
\text { deciduous classes. }\end{array}$ \\
\hline Road & $\begin{array}{l}\text { Land that predominantly built-up or developed and } \\
\text { vegetation associated with these land covers. Within the } \\
\text { study site, these areas are known to be roads. }\end{array}$ \\
\hline Rock Barrens & $\begin{array}{l}\text { Land that is predominately non-vegetated and non- } \\
\text { developed. Within the study site these areas are exposed } \\
\text { bedrock with thin soils and small patches of vegetation. }\end{array}$ \\
\hline Shrubland & $\begin{array}{l}\text { Predominantly woody vegetation of relatively low height } \\
\text { (generally }+/-2 \text { meters). May include grass or wetlands } \\
\text { with woody vegetation, regenerating forest. }\end{array}$ \\
\hline Water & Water bodies (lakes, rivers, streams, etc). \\
\hline Wetland & $\begin{array}{l}\text { Land with a water table near/at/above soil surface for } \\
\text { enough time to promote } \\
\text { wetland or aquatic processes (semi-permanent or } \\
\text { permanent wetland vegetation, including fens, bogs, } \\
\text { swamps, sloughs, marshes etc). }\end{array}$ \\
\hline
\end{tabular}

We then overlaid diurnal and nocturnal UTM coordinates from tracked Whip-poor-wills on to the land cover types and used separate RSFs to analyze daytime versus nighttime locations (Fig. 1). Within the larger Torrance Barrens area ( 769 ha), the boundary of the study site was defined by the minimum bounding polygon around all Whip-poor-will locations plus an additional $15 \mathrm{~m}$ buffer (total of $375 \mathrm{ha}$ ). The $15 \mathrm{~m}$ extension of the minimum bounding polygon ensured that land cover types were included in the $15 \mathrm{~m}$ buffers for locations occurring right on the edge of the minimum bounding polygon. English et al. (2017b) noted that Whip-poor-wills defended an area spanning $4-10$ ha, and given observations made while capturing and tracking individuals in our study, we assumed that tagged Whip-poor-wills were able to go anywhere within a larger home range similar to the size of our defined study area.

\section{Resource selection function (RSF)}

RSFs typically compare a group of locations used by an animal ("used locations") to a group of locations that were available to the animal within a given timeframe ("available locations"; Manly 1993, Boyce and McDonald 1999). Available locations were randomly placed within the boundary of the study site (Fig. 1). Following the recommendation by Nad'o and Kaňuch (2018), we paired each used location to 10 random locations. We, therefore, had 89 used daytime locations, 890 available daytime locations, 358 used nighttime locations, and 3580 available nighttime locations. To account for the $+/-5 \mathrm{~m}$ accuracy of GPS locations (Dauwalter et al. 2006) and the accuracy of the land cover layer (Agriculture and Agri-Food Canada 2019), a buffer with a $15 \mathrm{~m}$ radius was placed around both the used and available locations. The small size of the buffer greatly reduced issues with contamination, which arises when the sample of used locations overlaps excessively with the sample of available locations (Johnson et al. 2006). Using GIS, we then found the area $\left(\mathrm{m}^{2}\right)$ of each land cover type within the buffers, which we later converted to a proportion relative to the total area in the buffer (Fig. 1).

To estimate whether Whip-poor-wills used some land cover types more than others in proportion to their availability, a third-order RSF (see Johnson 1980) was used to compare land cover types at "used" and "available" Whip-poor-will locations (Design I Type A RSF, as described in Manly 1993). The RSF assessed whether the probability of a Whip-poor-will using a given land cover type was proportional to how much of that habitat was available (Boyce et al. 2002). Locations were grouped according to time of day (i.e., daytime or nighttime), and diurnal and nocturnal habitat selection were analyzed using separate RSFs. Binomial generalized linear mixed models (GLMMs) with a logit link function were used to estimate the probability that a given land cover type would be preferred by a Whip-poor-will. Prior to formal analysis, we assessed the correlation between each land cover type. While none were highly correlated (i.e., all correlation coefficients were less than 0.8 ) several showed a moderate degree of correlation with coefficients between 0.19 to 0.29 , which may have explained why models either failed to converge and/or showed strong signs of multi-collinearity when we incorporated multiple land cover variables in the same model. Thus, each land cover type was analyzed using a separate GLMM to allow for model convergence and reduce issues of multicollinearity. We note that this is not ideal and therefore emphasize that our results should be interpreted accordingly. The binary response variable in the models represented whether a location was used (1) or available (0), with the proportion of each land cover category used as the fixed effect and individual ID included as a random effect. The output of the RSF model is a coefficient of selection estimate $(\beta)$. A positive $\beta$ indicated preference for a given land cover type and a negative $\beta$ indicated the habitat was not preferred. As $\beta$ becomes closer to 0 , the degree of preference for the land cover type becomes weaker. The alpha value for all models was set at 0.05 .

\section{RESULTS}

Based on the random points generated for each used location, the most abundant available land cover types were shrubland (33\% for nighttime, $35 \%$ for daytime), wetland ( $23 \%$ for nighttime, $21 \%$ for daytime), and rock barrens (17\% for both periods), while the least abundant land cover types were road (3\% for both periods), water ( $6 \%$ for both periods), and deciduous forest ( $7 \%$ for both periods; Table 1). 
Table 3. Selection coefficients $(\beta)$ and confidence intervals estimated from binomial logistic regression model for Whip-poor-will habitat selection during daytime and nighttime within $15 \mathrm{~m}$ radius location buffers at Torrance Barrens, Ontario in the 2018 - 2020 breeding seasons. Positive $\beta$ estimates \pm standard error indicate preference for that land cover type and negative values indicate avoidance $(*$ indicates significance at alpha $=0.05$ ). Confidence intervals that overlap with zero suggest there is little evidence for either preference or avoidance of that land cover type.

\begin{tabular}{|c|c|c|c|c|c|}
\hline Time of Day & Land Cover Type & $\begin{array}{c}\text { Selection } \\
\text { Coefficient }(\beta)\end{array}$ & $2.5 \% \mathrm{CI}$ & $97.5 \% \mathrm{CI}$ & $\mathrm{p}$ \\
\hline \multirow[t]{7}{*}{ Night } & Deciduous Forest & $0.001 \pm 0.0003$ & $<0.001$ & 0.001 & $0.024 *$ \\
\hline & Mixed Forest & $0.0004 \pm 0.001$ & 0.0004 & 0.001 & $<0.001^{*}$ \\
\hline & Road & $-0.0003 \pm 0.0006$ & -0.002 & 0.001 & 0.68 \\
\hline & Rock Barrens & $0.001 \pm 0.002$ & $<0.001$ & 0.001 & $0.02 *$ \\
\hline & Shrubland & $0.001 \pm 0.0002$ & 0.0004 & 0.001 & $<0.001^{*}$ \\
\hline & Water & $-0.01 \pm 0.002$ & -0.01 & -0.004 & $0.001^{*}$ \\
\hline & Wetland & $-0.002 \pm 0.0003$ & -0.003 & -0.001 & $<0.001^{*}$ \\
\hline \multirow[t]{7}{*}{ Day } & Deciduous Forest & $0.003 \pm 0.0005$ & 0.002 & 0.003 & $<0.001^{*}$ \\
\hline & Mixed Forest & $-0.0006 \pm 0.001$ & -0.002 & 0.001 & 0.38 \\
\hline & Road & $-0.005 \pm 0.003$ & -0.015 & $<-0.001$ & 0.17 \\
\hline & Rock Barrens & $-0.0001 \pm 0.001$ & -0.001 & 0.001 & 0.72 \\
\hline & Shrubland & $0.001 \pm 0.0004$ & 0.0002 & 0.002 & $0.02 *$ \\
\hline & Water & $-0.01 \pm 0.007$ & -0.03 & -0.003 & $0.13^{*}$ \\
\hline & Wetland & $-0.002 \pm 0.007$ & -0.004 & -0.001 & $0.002 *$ \\
\hline
\end{tabular}

At night, Whip-poor-wills preferred areas with higher amounts of rock barrens, deciduous forest, mixed forest, and shrubland (Table 3, Fig. 2). Rock barrens, deciduous forest, mixed forest, and shrubland comprised $21 \%, 9 \%, 16 \%$, and $41 \%$ of the area around used locations, respectively (Table 1). At night, Whippoor-wills did not prefer water and wetlands; roads were used proportionally with available land cover (Table 3).

During the day, Whip-poor-wills preferred roosting sites in deciduous forest and shrubland, which comprised $22 \%$ and $45 \%$, respectively, of the area around locations (Tables 1 and 3, Fig. 2). They rarely used wetlands and water, while rock barrens, roads and mixed forest were used proportional to what was available (Table 3).

\section{DISCUSSION}

Here, we demonstrate that Whip-poor-wills at Torrance Barrens preferred deciduous forest and early successional shrubland for diurnal roosting and nocturnal foraging or singing. The preference of deciduous forest for daytime roosts lends partial support to our predator avoidance hypothesis, but interestingly, Whip-poor-wills preferred mixed forest more than available only at nighttime. Though not considered in the predator avoidance hypothesis, it is possible that shrubland, which is largely dominated by common juniper at Torrance Barrens, provides similar camouflage benefits for roosting Whip-poor-wills given that dead oak leaves tend to collect on the ground amidst low juniper branches at the study site. Our findings align with Akresh and King (2016), who at their pitch-pine and scrub-oak barrens site in Massachusetts, found Whip-poor-wills roosting predominantly in shrubland during the day. However, we also found some Whip-poor-wills roosting in pitch pine and closedcanopy forest, only to a lesser extent. Akresh and King (2016) noted that their effort searching closed-canopy forest for Whippoor-wills was minimal.
We also provide partial support for the optimal foraging hypothesis, with Whip-poor-wills preferring rock barrens at nighttime. At night, Whip-poor-wills also preferred mixed forest $1.5 \mathrm{x}$ more than available, and additionally selected shrubland and deciduous forest, contrary to our predictions. Rock barrens at the study site are often interspersed with low, shrubby common juniper, and it is possible that shrubland at Torrance Barrens affords Whip-poor-wills the same visual foraging advantages as rock barrens. The preference of mixed and deciduous forests at night suggests that Whip-poor-wills benefit from the availability of perches for singing or for their sallying flights (Cink et al. 2020, Spiller 2019), reinforcing the importance of open patches juxtaposed by forest for the species. Forest structure influences habitat selection in a similar species, the European Nightjar (Caprimulgus europaeus), which also uses a mosaic of forest patches and open spaces (Sierro et al. 2001, Verstraeten et al. 2011).

Unexpectedly, Whip-poor-wills preferred deciduous forest during both daytime and nighttime but only preferred mixed forest only at nighttime, which may be due to food availability (English et al. 2017b) or competition for resources. In coniferous-dominated landscapes, for example, nocturnal flying insects are most abundant in pockets of deciduous forests (Mattson et al. 1987; Ober and Hayes 2008). In our study area, mixed forest is $1.6 \mathrm{x}$ more abundant than deciduous forests. Roosting in deciduous forest may provide easy access to foraging sites with high food availability as soon as dusk or nighttime conditions are suitable. Whip-poor-wills tend to forage immediately after getting up at dusk, and additionally, males are often prompt in counter-singing intruders calling near their roost site just after sunset (ERMG personal observation). It is therefore possible that roosting locations may also serve a territorial function. Although there is limited information on the territoriality of Whip-poor-wills (Cink et al. 2020), roosting in the same habitat used for nocturnal 
Fig. 2. Mean proportion of land cover types within used and available $15 \mathrm{~m}$ radius location buffers for daytime ( $\mathrm{n}=89$ used, 890 available) and nighttime $(\mathrm{n}=358$ used, 3,580 available) locations of Whip-poor-wills breeding at Torrance Barrens, Ontario, 2018-2020. Error bars are standard deviations. * above a given error bar indicates statistically significant selection according to resource selection function model (at alpha $=0.05$ ).

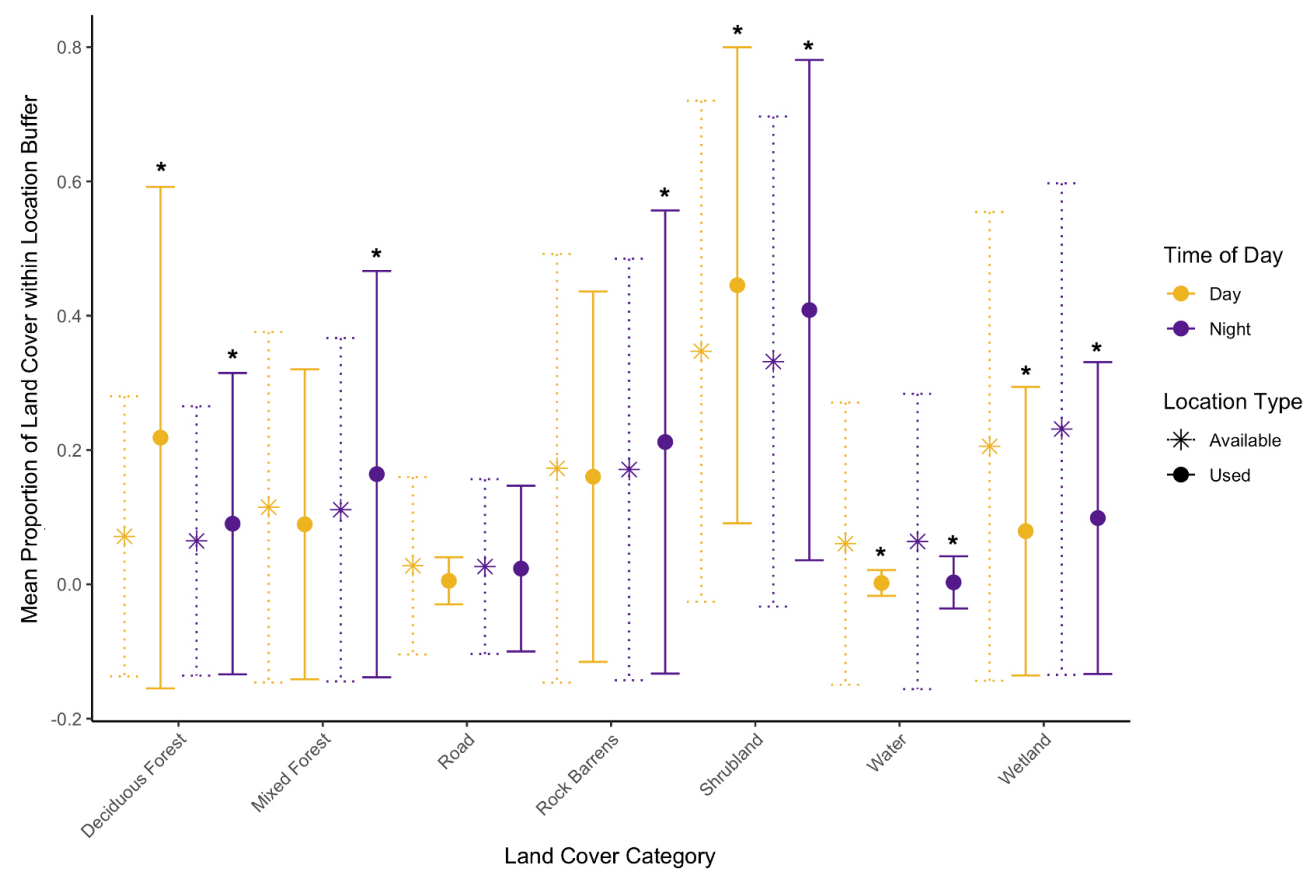

foraging may be one mechanism individuals use to reduce competition at foraging sites.

Whip-poor-wills used wetlands significantly less than expected given their availability, contrasting with recent studies on Whippoor-will habitat occupancy (Farrell et al. 2017, Vala et al. 2020). However, it is critical to note that given differences in methodology, the geographic scales used in these studies are relatively broad while our study quantified land cover covariates at a much more refined scale. Vala et. al. (2020) and Farrell et. al (2017) measured occupancy by using Automated Recording Units (ARUs) to determine presence or absence of individuals based on sound. Such methods do not take into account how Whippoor-will songs may vary with land cover, nor diurnal versus nocturnal differences in calling. These aforementioned studies showed that Whip-poor-wills occupied wetlands in close proximity to forest patches at relatively large spatial scales. By contrast, our study examined habitat preference, which allowed us to include locations representing numerous behavioral states (e.g. roosting, foraging, etc.) as well as use small habitat buffers and account for repetition among used areas. Contrary to these occupancy studies, our habitat preference analysis suggests Whippoor-wills do not prefer wetlands, but they may occupy areas near or above wetlands where they may sing or forage. However, it is critical to note that our manual telemetry methods likely introduce sampling bias as tracking a nocturnal bird quickly through wetlands to obtain a GPS location is incredibly difficult. Furthermore, although we were unable to analyze the four distinct wetland types at our study site (bog, fen, marsh, and swamp) as separate variables in our analysis, it is plausible that wetlands, such as tamarack bogs, thicket swamps, and fens contain more suitable foraging perches than open sphagnum bogs and marshes. Thus, it remains possible that Whip-poor-wills require wetlands in the broader landscape, and more study is needed to determine the relative importance of wetlands (including wetland type) for Whip-poor-wills across multiple spatial scales.

We illustrate the importance of considering both daytime and nighttime habitat preference when making decisions regarding land protection for species of conservation concern. Based on the p-values and confidence intervals (Table 3), there was evidence for stronger selection of mixed forest than deciduous forest by Whip-poor-wills at nighttime, but during the daytime individuals selected only deciduous forest. This suggests that deciduous forest may provide benefits for both diurnal roosting and nocturnal activities like singing and foraging, while mixed forest is seemingly used more for nighttime activities alone. Similarly, though rock barrens may provide open areas for nighttime activity such as foraging, they may not provide the features preferred by Whippoor-wills for roosting. While roosting locations may comprise a relatively small proportion of a bird's home-range, habitat preference for roosting may affect energy-expenditure and survival. In Australian Owlet-nightjars (Aegotheles cristatus), birds roosting in tree cavities were twice as likely to enter torpor as compared to those roosting in rock crevices. Despite this, tree cavities were more commonly used than rock crevices for roosting, and the use of both roost types may illustrate a trade-off between thermoregulation and concealment from predators (Doucette et 
al. 2011). Little Owls (Athene noctua) that regularly selected sheltered roosts like tree cavities and nest boxes had higher survival rates than those that regularly selected exposed roosts, but sheltered sites were more commonly used during cold temperatures, suggesting that roost site selection was driven by both predator avoidance and thermoregulation (Bock et al. 2013). In Tawny Owls (Strix aluco), low, exposed diurnal roosts used for daytime foraging were most often selected by juveniles who risked greater risk of predation as a result (Stunde et al. 2003). Though Whip-poor-wills are not cavity nesters like the aforementioned examples, diurnal roosting makes daytime camouflage particularly important for avoiding detection by predators (Spiller 2019, Cink et al. 2020). Whip-poor-wills can also enter brief periods of torpor to conserve energy during cold periods (Cink et al. 2020) and certain forest types may be more beneficial for thermoregulation or foraging immediately after sunset. The combination of evidence regarding the importance of roost site preference indicates that land cover types used during resting periods should be considered critical habitat when making conservation decisions.

In summary, we demonstrate that Whip-poor-wills breeding in central Ontario select shrubland as well as deciduous forest more often than available throughout daytime and nighttime and additionally prefer rock barrens and mixed forest at night. While Torrance Barrens does not feature other open habitat such as burns, clearcuts, and grasslands, it is noteworthy that the site's windswept granite ridges preclude vegetative growth without the necessity of management strategies such as prescribed fire or selective tree cutting for maintaining open forest patches. Conserving similar rock barrens landscapes could be particularly beneficial for the species. The consistency of these habitat preference patterns across the breeding range is unknown, and furthermore, it is likely that habitat preference changes according to different periods of the annual cycle. Whip-poor-wills are a threatened species in Canada, and information on specific habitat requirements in Ontario will help inform policy and management decisions in this region and throughout the northern extent of their breeding range. Conservation efforts for Whip-poor-wills on the northern breeding grounds should prioritize surveying and protecting similar rock barrens landscapes as well as open forest habitat with a comparable patchwork of land cover features.

Responses to this article can be read online at: https://www.ace-eco.org/issues/responses.php/1929

\section{Acknowledgments:}

Our study site is within lands of the Robinson-Huron Treaty of 1850 and the Williams Treaties of 1923. It is the traditional territory of the Anishinaabek and Huron-Wendat. We acknowledge those who shared with us their traditional knowledge of whip-poor-wills. We learned from Sherrill Judge of Shawanaga First Nation and Brian McInnes from Wasauksing First Nation that whip-poor-wills are recognized by multiple names in Anishinaabek culture. These names include waakowazh, waawoonese (used by Sam Kewaquado from Shawanaga First Nation), and waakaale (used by Stewart
King from Wasauksing First Nation). This work was approved by the University of Guelph Animal Utilization Protocol (permit 3946) and permission to capture birds was obtained from the Canadian Wildlife Service. We are thankful to Eloise A. HindSmith, Karl T. Heide, Megan A. Buers, Siobhan Darlington, and Becca J. Howe for field assistance, James Paterson for statistical advice, and Adam Bonnycastle for GIS advice. We also thank two anonymous reviewers, the associate editor, and Dr. Alex Bond for helpful and insightful comments on this manuscript. This research corresponds with the current laws in Canada. Funding was provided from the Natural Sciences and Engineering Council of Canada (Discovery Grant to DRN), The American Ornithological Society, The McLean Foundation, and Pattern Energy Group Inc., and the Species at Risk Stewarship Program. EAG was supported by the Liber Ero Foundation. Additional support and field housing were provided by Georgian Bay Land Trust in cooperation with the Couchiching Conservancy.

\section{LITERATURE CITED}

Agriculture and Agri-Food Canada. 2019. Annual space-based crop inventory for Canada, 2019, electronic dataset. Agriculture and Agri-Food Canada. [online] URL: https://open.canada.ca/ data/en/dataset/d90a56e8-de27-4354-b8ee-33e08546b4fc.

Akresh, M., and D. King. 2016. Eastern Whip-poor-will breeding ecology in relation to habitat management in a pitch pine-scrub oak barren. Wildlife Society Bulletin 40:97-105. https://doi. org/10.1002/wsb.621

Ashdown, R. A. M., and A. E. McKechnie. 2008. Environmental correlates of Freckled Nightjar (Caprimulgus tristigma) activity in a seasonal, subtropical habitat. Journal of Ornithology 149:615-619. https://doi.org/10.1007/s10336-008-0309-7

Baldwin, R. F., A. J. K. Calhoun, and P. G. deMaynadier. 2006. Conservation planning for amphibian species with complex habitat requirements: a case study using movements and habitat selection of the wood frog, Rana sylvatica. Journal of Herpetology 40:442-453. https://doi.org/10.1670/0022-1511(2006) 40[442:CPFASW]2.0.CO;2

Beyer, H. L., D. T. Haydon, J. M. Morales, J. L. Frair, M. Hebblewhite, M. Mitchell, and J. Matthiopoulos. 2010. The interpretation of habitat preference metrics under use-availability designs. Philosophical Transactions of the Royal Society B: Biological Sciences 365:2245-2254. https://doi.org/10.1098/ rstb. 2010.0083

Bock, A., B. Naef-Daenzer, H. Keil, F. Korner-Nievergelt, M. Perrig, and M. U. Grüebler. 2013. Roost site selection by Little Owls, Athene noctua in relation to environmental conditions and life-history stages. Ibis 155:847-856. https://doi.org/10.1111/ ibi. 12081

Boyce, M. S., and L. L. McDonald. 1999. Relating populations to habitats using resource selection functions. Trends in Ecology \& Evolution 14:268-272. https://doi.org/10.1016/S0169-5347(99) 01593-1

Boyce, M. S., P. R. Vernier, S. E. Nielsen, and F. K. A. Schmiegelow. 2002. Evaluating resource selection functions. 
Ecological Modelling 157:281-300. https://doi.org/10.1016/ S0304-3800(02)00200-4

Boyce, M. S., and J. S. Waller. 2003. Grizzly bears for the bitterroot: predicting potential abundance and distribution. Wildlife Society Bulletin 31:670-683. [online] URL: https://www. jstor.org/stable/3784586

Burford, L. S., M. J. Lacki, and C. V. Covell. 1999. Occurrence of moths among habitats in a mixed mesophytic forest: implications for management of forest bats. Forest Science 45:323-332.

Cink, C. L., P. Pyle, and M. A. Patten. 2020.Eastern Whip-poorwill (Antrostomus vociferus). In P. G. Rodewald, editor. Birds of the World. Cornell Lab of Ornithology, Ithaca, NY, USA. https:// doi.org/10.2173/bow.whip-p1.01

Cleere, N. 1998. Nightjars: a guide to nightjars, nighthawks, and their relatives. Yale University Press, New Haven, Connecticut, USA.

COSEWIC. 2009. COSEWIC assessment and status report on the Whip-poor-will Caprimulgus vociferus in Canada. Committee on the Status of Endangered Wildlife in Canada (COSEWIC), Ottawa, Ontario. [online] URL: https://www. sararegistry.gc.ca/virtual_sara/files/cosewic/sr_whip-poor-will_0809_e. pdf

Dauwalter, D. C., W. L. Fisher, and K. C. Belt. 2006. Mapping stream habitats with a global positioning system: accuracy, precision, and comparison with traditional methods. Environmental Management 37:271-280. https://doi.org/10.1007/ s00267-004-0270-Z

Doucette, L. I., R. M. Brigham, C. R. Pavey, and F. Geiser. 2011. Roost type influences torpor use by Australian Owlet-nightjars. Die Naturwissenschaften 98:845-854. https://doi.org/10.1007/ s00114-011-0835-7

English, P. A., A. M. Mills, M. D. Cadman, A. E. Heagy, G. J. Rand, D. J. Green, and J. J. Nocera. 2017a. Tracking the migration of a nocturnal aerial insectivore in the Americas. BMC Zoology 2:5. https://doi.org/10.1186/s40850-017-0014-1

English, P. A., J. J. Nocera, B. A. Pond, and D. J. Green. 2017b. Habitat and food supply across multiple spatial scales influence the distribution and abundance of a nocturnal aerial insectivore. Landscape Ecology 32:343-359. https://doi.org/10.1007/s10980-016-0454$\mathrm{y}$

Farrell, C. E., S. Wilson, and G. Mitchell. 2017. Assessing the relative use of clearcuts, burned stands, and wetlands as breeding habitat for two declining aerial insectivores in the boreal forest. Forest Ecology and Management 386:62-70. https://doi. org/10.1016/j.foreco.2016.11.026

Fisher, R. J., Q. E. Fletcher, C. K. R. Willis, and R. M. Brigham. 2004. Roost selection and roosting behavior of male Common Nighthawks. The American Midland Naturalist 151:79-87. [online] URL: https://www.jstor.org/stable/3566789

Foley, G.J., 2018. Habitat use by Common Nighthawks (Chordeiles minor) in Canada's boreal forest. Master's Thesis. University of Regina. [online] URL: https://ourspace.uregina.ca/ bitstream/handle/10294/8886/Foley_Gabriel_MSC_BIOL_Spring2019. pdf
Framis, H., G. Holroy, and S. Manosa. 2011. Home range and habitat use of Little Owl (Athene noctua) in an agricultural landscape in coastal Catalonia, Spain. Animal Biodiversity and Conservation 34:369-378.

Franklin, A. B., D. R. Anderson, R. J. Gutiérrez, and K. P. Burnham. 2000. Climate, habitat quality, and fitness in Northern Spotted Owl populations in Northwestern California. Ecological Monographs 70:539-590. https://doi.org/10.1890/0012-9615 (2000)070[0539:CHQAFI]2.0.CO;2

Fretwell, S. D., and J. S. Calver. 1969. On territorial behavior and other factors influencing habitat distribution in birds. Acta Biotheoretica 19:37-44.

Garlapow, R. M. 2007. Whip-poor-will prey availability and foraging habitat: implications for management in pitch pine / scrub oak barrens habitats. Master's Thesis. University of Massachusetts Amherst. [online] URL: https://core.ac.uk/ download/pdf/13599317.pdf

Gillings, S., R. J. Fuller, and W. J. Sutherland. 2005. Diurnal studies do not predict nocturnal habitat choice and site selection of European Golden-Plovers (Pluvialis apricaria) and Northern Lapwings (Vanellus vanellus). The Auk 122:1249-1260. https:// doi.org/10.1642/0004-8038(2005)122[1249:DSDNPN]2.0.CO;2

Johnson, C. J., S. E. Nielsen, E. H. Merrill, T. L. McDonald, and M. S. Boyce. 2006. Resource selection functions based on useavailability data: theoretical motivation and evaluation methods. The Journal of Wildlife Management 70:347-357. https://doi. org/10.2193/0022-541X(2006)70[347:RSFBOU]2.0.CO;2

Johnson, D. H. 1980. The comparison of usage and availability measurements for evaluating resource preference. Ecology 61:65-71. https://doi.org/10.2307/1937156

Körtner, G., and F. Geiser. 1999. Roosting behaviour of the Tawny Frogmouth (Podargus strigoides). Journal of Zoology 248:501-507. https://doi.org/10.1111/j.1469-7998.1999.tb01049.x

Krebs, J. R., J. T. Erichsen, M. I. Webber, and E. L. Charnov. 1977. Optimal prey selection in the Great Tit (Parus major). Animal Behaviour 25:30-38. https://doi.org/10.1016/0003-3472 (77)90064-1

Krebs, J.R. 1978. Optimal foraging: decision rules for predators. In J. R. Krebs and Davies, N.B., editors. Behavioural ecology: an evolutionary approach. Blackwell, Oxford, UK.

Lima, S. L., and L. M. Dill. 1990. Behavioral decisions made under the risk of predation: a review and prospectus. Canadian Journal of Zoology 68:619-640. https://doi.org/10.1139/z90-092

Manly, B. F. J., 1944-. 1993. Resource selection by animals: statistical design and analysis for field studies, 1 st edn. Chapman \& Hall, London, UK.

Masse, R. J., B. C. Tefft, J. A. Amador, and S. R. McWilliams. 2013. Why woodcock commute: testing the foraging-benefit and predation-risk hypotheses. Behavioral Ecology 24:1348-1355. https://doi.org/10.1093/beheco/art073

Mattson, W. J., J. M. Scriber, and J. Rodriguez. 1987. Nutritional ecology of insect folivores of woody plants: nitrogen, water, fiber, and mineral considerations. In F. Slanksy Jr., editor. Nutritional 
ecology of insects, mites, spiders, and related invertebrates. Wiley, New York, New York, USA.

McGarigal, K., H. Y. Wan, K. A. Zeller, B. C. Timm, and S. A. Cushman. 2016. Multi-scale habitat selection modeling: a review and outlook. Landscape Ecology. https://doi.org/10.1007/ s10980-016-0374-x

Mills, A. 2007. Whip-poor-will. In M. D. Cadman, D. A. Sutherland, G. G. Beck, D. Lepage, and A. Couturier R., editors. Atlas of the breeding birds of Ontario, 2001-2005. Bird Studies Canada, Environment Canada, Ontario Field Ornithologists, Ontario Ministry of Natural Resources \& Ontario Nature, Toronto, Ontario.

Mills, A. M. 1986. The Influence of moonlight on the behavior of goatsuckers (Caprimulgidae). The Auk 103:370-378. [online] URL: https://sora.unm.edu/sites/default/files/journals/auk/v103n02/ p0370-p0378.pdf

Moe, T. F., J. Kindberg, I. Jansson, and J. E. Swenson. 2007. Importance of diel behaviour when studying habitat selection: examples from female Scandinavian brown bears (Ursus arctos). Canadian Journal of Zoology 85:518-525. https://doi. org/10.1139/Z07-034

Murphy, H. T., and J. Lovett-Doust. 2007. Accounting for regional niche variation in habitat suitability models. Oikos 116:99-110. https://doi.org/10.1111/j.2006.0030-1299.15050.x

Nad'o, L., and P. Kaňuch. 2018. Why sampling ratio matters: logistic regression and studies of habitat use. PLOS ONE 13: e0200742. https://doi.org/10.1371/journal.pone.0200742

Ng, J. W., E. C. Knight, A. L. Scarpignato, A.-L. Harrison, E. M. Bayne, and P. P. Marra. 2018. First full annual cycle tracking of a declining aerial insectivorous bird, the Common Nighthawk (Chordeiles minor), identifies migration routes, nonbreeding habitat, and breeding site fidelity. Canadian Journal of Zoology 96:869-875. https://doi.org/10.1139/cjz-2017-0098

Ober, H. K., and J. P. Hayes. 2008. Influence of forest riparian vegetation on abundance and biomass of nocturnal flying insects. Forest Ecology and Management 256:1124-1132. https://doi. org/10.1016/j.foreco.2008.06.010

Osborne, P. E., and P. J. Seddon. 2012. Selecting suitable habitats for reintroductions: variation, change and the role of species distribution modelling. In J. G. Ewen, D. P. Armstrong, K. A. Parker, and P. J. Seddon, editors. Reintroduction Biology. Blackwell Publishing Ltd, Hoboken, New Jersey, USA. https:// doi.org/10.1002/9781444355833.ch3

Rand, G. J. 2014. Home range use, habitat selection, and stress physiology of eastern whip-poor-wills (Antrostomus vociferus) at the northern edge of their range. Master's Thesis. Trent University. [online] URL: http://digitalcollections.trentu.ca/ objects/etd-286

Sharov, A. A., A. M. Liebhold, and E. A. Roberts. 1997. Correlation of counts of gypsy moths (Lepidoptera: Lymantriidae) in pheromone traps with landscape characteristics. Forest Science 43:483-490.

Sharps, K., I. Henderson, G. Conway, N. Armour-Chelu, and P. M. Dolman. 2015. Home-range size and habitat use of European
Nightjars Caprimulgus europaeus nesting in a complex plantation-forest landscape. Ibis 157:260-272. https://doi. org/10.1111/ibi.12251

Sierro, A., R. Arlettaz, B. Naef-Daenzer, S. Strebel, and N. Zbinden. 2001. Habitat use and foraging ecology of the nightjar (Caprimulgus europaeus) in the Swiss Alps: towards a conservation scheme. Biological Conservation 98:325-331. https://doi.org/10.1016/S0006-3207(00)00175-0

Smith, A. C., M.-A. R. Hudson, V. Aponte, and C. M. Francis. 2017. North American breeding bird survey - Canadian trends website. Environment and Climate Change Canada. [online] URL: https://wildlife-species.canada.ca/breeding-bird-surveyresults/P001/A001/?lang=e

Spiller, K. 2019. Eastern Whip-poor-will habitat associations in Fort Drum, NY. Master's Thesis. University of Massachusetts Amherst. [online] URL: https://scholarworks.umass.edu/ masters_theses_2/797/

Stevens, M., J. Troscianko, J. K. Wilson-Aggarwal, and C. N. Spottiswoode. 2017. Improvement of individual camouflage through background choice in ground-nesting birds. Nature Ecology \& Evolution 1:1325-1333. https://doi.org/10.1038/ s41559-017-0256-x

Summerville, K. S., and T. O. Crist. 2003. Determinants of lepidopteran community composition and species diversity in eastern deciduous forests: roles of season, eco-region and patch size. Oikos 100:134-148. https://doi.org/10.1034/j.1600-0706.2003.11992. $\mathrm{x}$

Sunde, P., M. S. Bølstad, and K. B. Desfor. 2003. Diurnal exposure as a risk sensitive behaviour in Tawny Owls (Strix aluco)? Journal of Avian Biology 34:409-418. https://doi.org/10.1111/

j.0908-8857.2003.03105.x

Tonra, C. M., J. R. Wright, and S. N. Matthews. 2019. Remote estimation of overwintering home ranges in an elusive, migratory nocturnal bird. Ecology and Evolution ece3.5723. https://doi. org/10.1002/ece 3.5723

Tozer, D. C., J. C. Hoare, J. E. Inglis, J. Yaraskavitch, H. Kitching, and S. Dobbyn. 2014. Clearcut with seed trees in red pine forests associated with increased occupancy by Eastern Whip-poor-wills. Forest Ecology and Management 330:1-7. https://doi. org/10.1016/j.foreco.2014.06.038

Troscianko, J., J. Wilson-Aggarwal, M. Stevens, and C. N. Spottiswoode. 2016. Camouflage predicts survival in groundnesting birds. Scientific Reports 6:19966. https://doi.org/10.1038/ srep19966

Vala, M., G. Mitchell, K. Hannah, J. Put, and S. Wilson. 2020. The effects of landscape composition and configuration on Eastern Whip-poor-will (Caprimulgus vociferus) and Common Nighthawk (Chordeiles minor) occupancy in an agroecosystem. Avian Conservation and Ecology 15(1):24. https://doi. org/10.5751/ACE-01613-150124

Vallecillo, S., L. Brotons, and P. E. Osborne. 2010. Geographical variation in the distributional constraints along a gradient of population aggregation. Acta Oecologica 36:666-674. https://doi. org/10.1016/j.actao.2010.10.004

Verstraeten, G., L. Baeten, and K. Verheyen. 2011. Habitat 
preferences of European Nightjars Caprimulgus europaeus in forests on sandy soils. Bird Study 58:120-129. https://doi. org/10.1080/00063657.2010.547562

Wiens, J. A. 1985. Habitat selection in variable environments: shrub-steppe birds. In M. L. Cody, editor. Habitat Selection in Birds. Academic Press, Orlando, Florida, USA.

Wilson, M. D., and B. D. Watts. 2008. Landscape configuration effects on distribution and abundance of Whip-poor-wills. The Wilson Journal of Ornithology 120:778-783. https://doi. org/10.1676/06-108.1

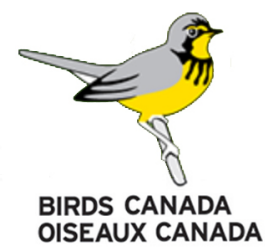


Appendix 1. R-code for analyses

Please click here to download file 'appendix1.r'. 
Avian Conservation and Ecology 16(2): 14

http://www.ace-eco.org/vol16/iss2/art14/

Appendix 2. Data used

Please click here to download file 'appendix2.csv'. 